FOCUS: Journal of International Business Volume 4, Issue 2, July-December 2017, pp. 26-43 doi: 10.17492/focus.v4i02.11687

\title{
Do Institutional Variables affect FDI inflows? A Panel Data Analysis of South Asian Countries
}

\author{
Vandana Goswami*
}

\begin{abstract}
The study addresses several questions related to the effect of institutional variables on foreign direct investment inflows in South Asian countries consisting of Afghanistan, Bangladesh, Bhutan, India, Maldives, Nepal, Pakistan and Sri Lanka. The institutional variables taken in the study include control of corruption, political instability, quality of governance, regulatory quality, and rule of law. The paper uses panel data for the period of 1990-2015. The objective of this paper is to study the impact of institutional determinants on FDI inflows in eight South Asian countries. The main findings of the paper indicate that government effectiveness and trade openness are having a positive impact on FDI inflows while control of corruption and regulatory quality have negatively affected FDI inflows in these eight South Asian Countries.
\end{abstract}

Keywords: Corruption; Political instability; Rule of law; Regulatory quality; FDI.

\subsection{Introduction}

Foreign direct investment (FDI) is often taken as synonym for the development, where every country is in a race to attract more and more FDI. It has been identified as an important source of financing for developed as well as developing countries. It is generally perceived that FDI plays a remarkable role in the development and growth of a country. It proves to be a source of fund for a nation where domestic investments are not adequate for development. FDI not only endows with capital but it also provides modern technology, managerial know how etc. to the host country. FDI is international investment in the financial or non-financial corporate sectors of the economy in which the non-resident investor purchases 10 percent or more of the voting power of an incorporated enterprise or has the equivalent ownership in an enterprise, operating under another legal structure (IMF, 2004).

*Assistant Professor; Satyawati College (M), University of Delhi, Delhi, India. (Email id: vandana.goswami.2006@gmail.com) 
Allowing and facilitating FDI into South Asian countries is one of the most important step of these countries. Initially South Asian region was not much influential for the foreign investors but recently the region is gaining the attention of foreign investors. However, when South Asian region is compared with other Asian regions and developing countries, we observe that it receives relatively low FDI inflows. This paper is an attempt to understand the reasons behind low FDI inflows in reference to the impact of institutional environment.

\subsection{Overview of FDI inflows}

World FDI inflows have reached US\$1.52 trillion in the year 2016, which is a fall of 13\% from the year 2015 (Figure 1). The share of developed economies in world FDI flows as a whole is estimated to have risen further, reaching 57\% of the total (World Development Indicators, World Bank). Inflows to the developing economies fell 20\% (to an estimated US\$600 billion), due to significant decrease in FDI inflows to developing Asia, Latin America and the Caribbean. FDI flows to transition economies rose by $38 \%$ to an estimated US\$52 billion (World Bank). In view of the importance of FDI inflows, the South Asian countries are also taking various measures to further liberalise their countries in order to attract more FDI to their countries. The eight nations Afghanistan, Bangladesh, Bhutan, India, Maldives, Nepal, Pakistan and Sri-Lanka come under the region of South Asia.

Figure 1: FDI Inflows 1990-2015 of World and South Asian Countries

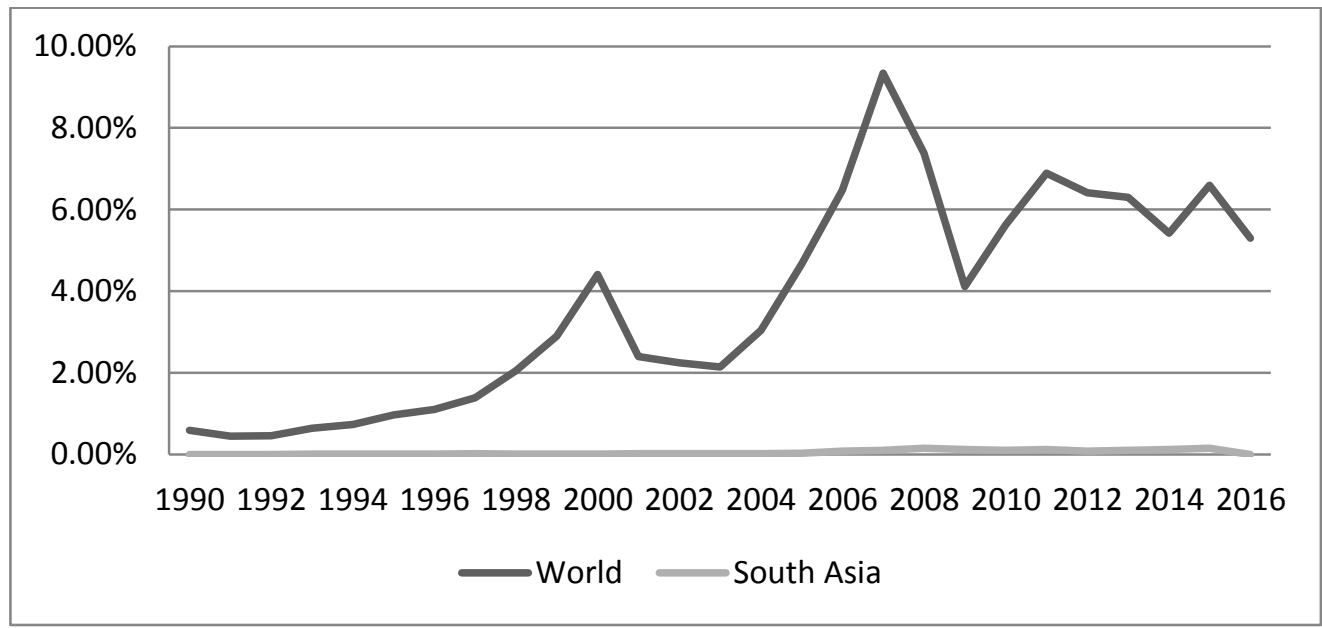

Source: World Bank 


\subsection{FDI inflows to South Asian countries: Some stylised facts}

The share of South Asian countries in developing Asia for FDI inflows for 19902015 has been presented in Figure 2. The share of FDI inflows in India is significantly rising as compared to other South Asian countries. In the year 2010 there was a fall in the inflows and it again rose in the year 2011 but it again experienced a fall in the year 2012 and is rising afterwards (World Bank). South Asian countries are attracting foreign direct investment from developed countries since the liberalisation reforms took place in their countries. The liberalisation of the policies in South Asian countries is making them as lucrative destinations for FDI. In South Asian countries India is among the top recipient of the foreign direct investment. Around 90\% of total FDI to the South Asia is directed to the Indian economy. (World Development Indicators, World Bank)

Figure 2: FDI Inflows 1990-2015 in South Asian Countries.

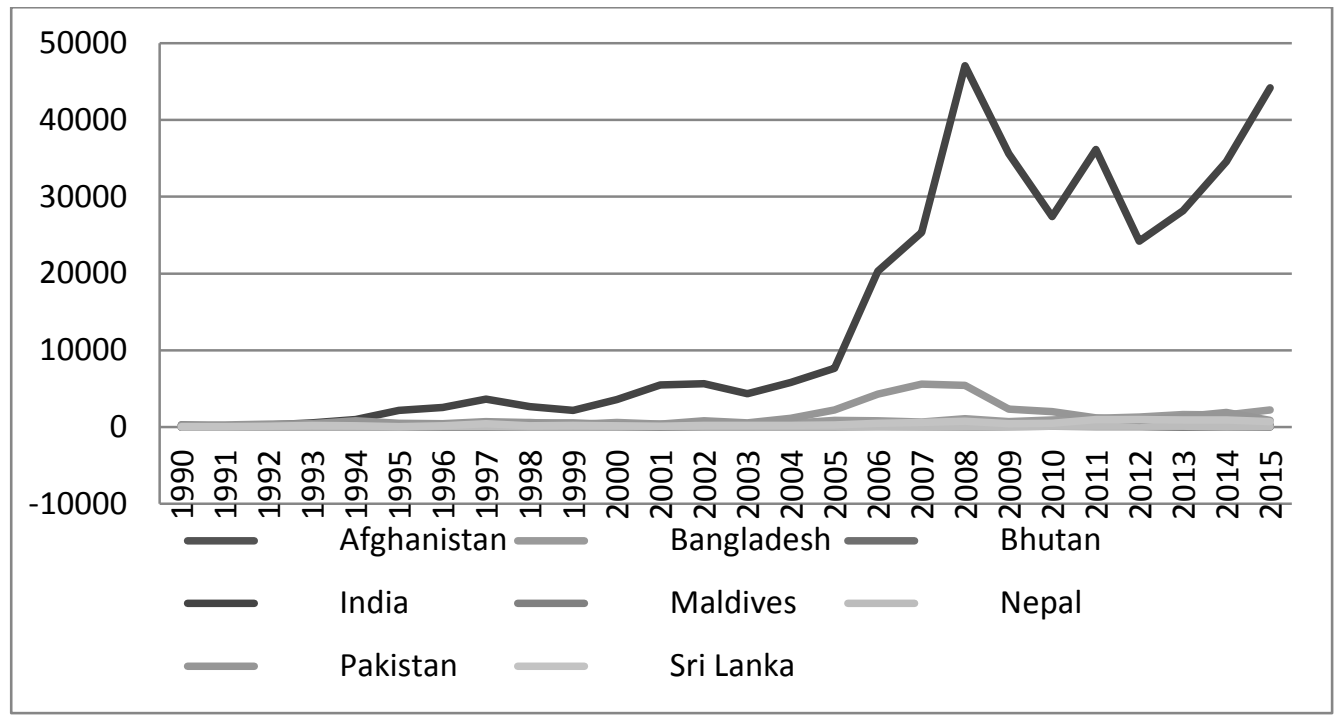

Source: World Bank

The other South Asian countries are facing challenges in attracting FDI inflows, despite taking various measures for liberalising policies and making environment more business friendly, the situation is not much improved. The South Asian countries share is 484347 million dollar in the year 2015 while it was 574.75 dollar in the year 1990. Out of this amount, India is the only dominated country with an amount of 44208 million dollar which is $91 \%$ of total FDI inflows received (author's calculations based on World Bank Reports). 
The share of FDI inflows in all other seven countries is very less when compared with the share of India. So here a number of questions arise that what are the determinants that affect the FDI inflows in these eight South Asian countries. The effect of macroeconomic variables has been studied by many authors, here with this paper we are attempting to find out the impact of institutional variables in these eight South Asian countries. The current paper has been further divided into five sections, the first section deals with the introduction of the study, second section deals with the review of literature, third section elucidates the objectives of the study, fourth section explains about the data and concerned research methodology, the fifth, section explains the empirical results and interpretation analysis, and sixth section describes the conclusion of the study.

\subsection{Literature Review}

Empirical studies show that the determinants of FDI flows in developing countries are different from FDI in developed countries. From the vast literature available, some of the studies have been reviewed here to understand which institutional determinants attract FDI in developed countries and developing countries.

Anghel (2005) examined the cross section data for the period of 1996- 2000 to find out the effect of different aspects of the quality of institutions on FDI by using ordinary least square (OLS) method by selecting corruption, protection of property rights, political stability, government effectiveness, regulatory quality, rule of law, inflation, trade openness and terms of trade etc. and concludes that poor institutions affect negatively to the amount of FDI. Grosse and Trevino (2005) linked the new institutional economies with organisational decision making on FDI. They employed data of 13 CEE countries for the period of 1990-1999. They selected corruption, rule of law, bilateral investment treaties, private sector share in GDP, inflation, political risk, exchange rate and GDP variables to analyse their effect on FDI. By using REM, GLS model findings confirm that bilateral investment treaties, the degree of enterprise reform, and repatriation rules tended to stimulate FDI, while political risk, and the level of corruption in government tended to constrain FDI into these countries Smarzynska and Wei (2000) studied the impact of corruption in host country on foreign Investor's choice of the entry mode. They found with empirical work that foreign investor with less diversified production structure are attracted towards transition economies, large markets, low tax rates and cheap labour. They also found that corruption in host country is associated with lower probability of investment. They concluded American investors are somewhat more reluctant to form joint ventures in more corrupt countries, possibly 
because of the U.S. foreign corrupt practices Act of 1977. Walsh and Yu (2010) studied 27 advanced countries. They used GMM based on Arellano- Bond Methodology to analyse macroeconomic variables such as openness, real exchange rate, GDP growth, FDI stock, Average inflation, GDP per capita and institutional variables such as labour market flexibility, judiciary independence, legal system efficiency, infrastructure quality and their relationship with primary FDI, secondary FDI and territory FDI. They concluded through their research that primary sector FDI has no strong linkage to macroeconomic stability, level of development, or institutional quality. But secondary and territory FDI appear to benefit from agglomeration or clustering effects. FDI in services appears to be much more strongly impacted by macroeconomic conditions than FDI in manufacturing. They observed that more flexible labour markets and deeper financial markets attract more secondary FDI.

Asiedu (2006) analysed the determinants of FDI in Africa by covering 22 countries of Sub Sahara Africa for the period of 1984-2000. The explanatory variables of the study are policy variables, institutional variables and political risk variables measured by market size, natural resources (share of fuel and minerals in exports), human capital measured by literacy rate, macroeconomic instability by inflation rate, FDI policy by openness to FDI, corruption, effectiveness of rule of law by no. of coups, no. of riots. By using fixed effect panel estimation, paper concluded that large local markets, natural resources, food infrastructure, low inflation, an efficient legal system and a good investment framework attract FDI, while corruption, political instability negatively affected FDI. Chen (2011) studied the location determinants, investor differences and economic impacts in China. He did empirical study of the determinants of regional inequality in the provinces of China. He applied modified gravity model and econometric regression analysis to test the hypotheses based on location advantages of the theory of FDI. He finds a country with larger market size, faster economic growth, higher per capital income, lower country risk in terms of economic, financial, institutional, social and political stability, higher quality of human resources with higher adult literacy rates, a higher level of existing FDI stock, higher degree of openness attract relatively more FDI. He also finds provinces with larger GDP, higher per capita income, higher rate of economic growth, higher level of openness, higher level of FDI stock, Infrastructure and labour quality attracts relatively more FDI. Deichmann et al (2008) studied the location determinants of FDI in developing countries. The study takes factors that determine location like agglomeration forces, market access, infrastructure, regulation and fiscal incentives. They suggested through systematic empirical analysis that preference of firms which have good market access and other agglomeration economies attract firms. Jadhav (2012) studied the determinants of foreign direct 
Investment in BRICS economies. He explores role of economic, institutional and political factors in attracting FDI in BRICS economies. He selected market size, trade openness, and natural resources as economic factors. Institutional and political factors include, inflation rate, political stability/No violence, government effectiveness, regulatory quality, control of corruption, accountabilities and rule of law. He concludes that economic factors are more significant than institutional and political factors in BRICS economies.

After reviewing the literature it has been observed that the institutional determinants have a significant impact on the level of FDI inflows. Though location determinants for the developed and developing countries are not same, still institutional determinants have almost same effect on FDI inflows across the world. The institutional determinants include, corruption, quality of government, labour market flexibility, quality of legal system, trade cost, fluctuation of exchange rates, political risk, openness, freedom of press, government stability, protection of IPR and government interventions etc. While observing effect of these determinants on inward FDI, we find consensus in the results like corruption has a negative impact (Walsh and Yu, 2010; Anghel, 2005; Du et al., 2012; Gross and Trevino, 2005). On the other hand regional IPR, protection of IPR, trade openness, political stability, government effectiveness, cheap labour and low tax rate has a significant positive impact on inward FDI (Belderbose and Caree, 2002; Smarzynska and Wei, 2000). The quality of institutions is becoming a very important determinant for attracting FDI into a country. A good legal system, less government interventions in operations, political stability, less corruption are the major factors of institution quality.

With the extensive literature review we found a gap in the study that the effect of institutional variables on South Asian countries has not been analysed so here we found the scope of finding the effect of institutional variables on eight South Asian countries i.e. Afghanistan, Bangladesh, Bhutan, India, Maldives, Nepal, Pakistan and Sri Lanka.

\subsection{Explanatory Variables}

\subsection{Control of corruption}

Corruption is usually defined as abuse of public office for private gains (World Bank, 1997). The higher the control on corruption implies a friendly environment for the host country, which enables the investor easily getting the work done without paying bribes to the authorities. Corruption may be defined as an act in which the power of public office is used for personal profits (Jain, 2001), so corruption is one of element of the institutional environment which may attract of distract the FDI inflows. The 
corruption may deter the level of FDI as it increases the cost of doing business (Jain 2001). Anghel (2005) examined the cross section data for the period of 1996- 2000 to find out the effect of different aspects of the quality of institutions on FDI by using ordinary least square (OLS) method. For measuring the quality of institutions of a country she selected corruption, protection of property rights, political stability, government effectiveness, regulatory quality, rule of law, inflation, trade openness and terms of trade etc. In conclusion part the study shows that the weak institutions have relatively less inflows of FDI into a country. According to empirical findings, poor institutions affect negatively to the amount of FDI.

Barassi and Zhou (2012) modelled the relationship between corruption and FDI using parametric and non- parametric analysis. To explain this, a large panel has been used for 20 OECD FDI source countries into 52 developed and developing host countries for the period of 1996-2003. Level of corruption in the host country has been taken as independent variable. Conclusion of the study explains that the overall effect of corruption is significantly negative on the likelihood of FDI. Godinez and Liu (2015) tried to explain the impact of corruption on FDI inflows into Latin America for the period of 2006-2009. The independent variables selected for the study are corruption, HDI, rule of law, bureaucracy, infrastructure quality, economic freedom, educational attainment, inflation, unemployment rate and GDP. They applied random effect logistic regression for correlation between variables, in order to test multicollinearity among variables Durbin Watson test applied. The conclusion part explains that FDI and corruption level has negative relationship. Pournarakis and Varsakelis (2004) attempted to explain the uneven allocation of FDI in the economies in transition. The independent variables of the study is quality of political institutions which is measured by political rights, political corruption and political discrimination, the other variables are civil liberties, and freedom of press, corruption perception and the degree of internalization, the dependent variables is FDI inflows per capita. They used ordinary least square method (OLS) to analyse the effect of these institutional variables on FDI. They conclude that favourable institutional environment attracts FDI. In this paper we argue that host country control of corruption measures have positive impact on foreign investors. This means host countries with higher level of control of corruption would attract more foreign direct investments, while host countries with lower level of control of corruption would not.

To measure the control of corruption the data has been taken from the governance indicators database, World Bank, estimates give the country's score, in units of a standard normal distribution, i.e. ranging from approximately -2.5 to 2.5 . 
Therefore we put forward the following research hypothesis:

Hypothesis 1. Host country control of corruption will have a positive association with inward FDI.

\subsection{Government effectiveness}

Institutional variables also refer to government effectiveness (La Porta et al., 1999) which is measured by the infrastructure development in a country, Cheng \& Kwan (2000) claim that foreign investment flows to regions with high road and railway density. Based on an industrial census dataset, Li \& Park (2006) show that multinationals favour the locations with better infrastructure, telecommunication and electricity facilities another study (Anghel B. 2005) concludes that the countries with low government effectiveness has relatively less FDI inflows. In light of the above arguments, we suggest that host countries with effective government would receive higher level of FDI inflows, while lower level of government effectiveness would deter the FDI inflows. The government effectiveness data has been obtained from World Governance Indicators, World Bank, the percentile rank indicates the country's rank among all countries covered by the aggregate indicator, with 0 corresponding to lowest rank, and 100 to highest rank. Therefore, we hypothesise as follows:

Hypothesis 2: Host country government effectiveness will have a positive association with inward FDI.

\subsection{Political stability}

Political stability is considered to be an important variable affecting decision to invest in an economy, the existing literature explains the importance of this variable, Okafor (2015) investigates the location determinants of U.S. FDI into Sub Saharan Africa (SSA). The author used panel data technique, for 23 countries of SSA for the period of 1996-2010. He selected natural resources, infrastructure development, market size, human capital, country risk (political instability and corruption), trade openness and inflation as the explanatory variables for the study and also developed hypothesis for each variable with relation to FDI. The study concludes that the availability of crude oil, internet user, GDP per capita, population growth rate encourages U.S. FDI into SSA. Political instability, corruption and exchange rates fluctuations are negatively insignificant. (Narayan L. 2014) concludes in his study for India that Political stability is found to be insignificant in almost all the cases thereby indicating that it is not a prime consideration for a foreign investor investing in India. To measure the Political Stability the data has been taken from the governance indicators database, World Bank, estimates give the country's score, in units of a standard normal distribution, i.e. ranging from 
approximately -2.5 to 2.5 In the light of the above, we argue that countries with higher political stability would attract more foreign direct investment while the political instability would deter the foreign investment. Therefore we formulate the hypothesis as follows:

Hypothesis 3: Host country Political stability will have a positive association with inward FDI.

\subsection{Trade openness}

Trade openness in general, is expected to have a positive impact on FDI. Open economies encourage more Foreign Investments. Brude et al (2014) investigate the impact of distance on FDI location. They modelled the panel dataset of 224 cities in China, independent variables taken for the study are attractiveness of the local market agglomeration economies, government expenditures on science, transport infrastructure, trade openness, labour cost, government spendings, and proportion of the population in the rural areas. By using Fixed and random effect model they conclude that foreign firms are influenced positively by local market attractiveness, human capital and trade openness. Martin et al (2014) attempted to identify the main determinants of FDI in Latin America for the period of 1990-2010, variables taken for the study are GDP per capita, trade openness, inflation, interest nominal, mobile phones, electricity losses, short term debt to reserves, current account balance (\% GDP), bureaucracy quality, control of corruption, government stability, law order risk and investment profile. They concluded that institutional variables play an important role in attracting FDI. To measure trade openness the export and import of these countries are added and a ratio of this addition to GDP per capita is taken. More open economies attract more FDI in the light of this we hypothesise as follows:

Hypothesis 4: Host country trade openness will have a positive association with inward FDI.

\subsection{Rule of law}

Rule of law is another important variable, it reflects the degree to which the citizens of a country are willing to accept the established institutions to make and implement laws and adjudicate disputes. A good rule of law includes sound political institutions, a strong court system, and provisions for an orderly succession of power. (Anghel, 2005; Godinez and Liu, 2015; Grosse and Trevino, 2005) confirm in their study that rule of law has positive effect on foreign inflows. The hypothesis is as follows 
Hypothesis 5: Host country Rule of Law will have a positive association with inward FDI.

\subsection{Regulatory quality}

Regulatory environment includes stable economic policy, non- corrupt bureaucracy, tax regulation, licencing and permit etc. Empirical studies show that government should take various regulatory measures in order to attract FDI including tariffs (Barnes and Davidson, 1994), taxes, subsidiaries (Rains and Brown, 1999), regulatory regime and revitalization policy (Curwen, 1997). A comparative global regulatory harmonisation influences the MNCs' internationalization policies (Dunning, 2001, 2002; Gatignon and Kimberly, 2004). The data for regulatory quality has been obtained from World Governance Indicators, World Bank, the percentile rank indicates the country's rank among all countries covered by the aggregate indicator, with 0 corresponding to lowest rank, and 100 to highest rank. The hypothesis for regulatory quality for the study is as follows:

Hypothesis 6: Host country Regulatory Quality will have a positive association with inward FDI.

\subsection{Voice and accountability}

Voice and accountability may be another important institutional variable for attracting FDI inflows into South Asian countries, voice and accountability denotes the participation ability of county's people to select their government, it includes freedom of press and media, freedom of expression and freedom of association. Some studies show that there is positive relation between FDI inflows and democracy Harns and Urprung (2002), Busse (2004), on the other hand some studies show that voice and accountability do not show significant influence on FDI inflows, such as Mangitsu and Adhikary (2011) states that voice and accountability do not show significant influence to FDI inflows, Jadhav (2012) concludes that Voice and Accountability has negative effect on total FDI inflows in BRICS economies. The data for Voice and Accountability has been obtained from World Governance Indicators, World Bank, the percentile rank indicates the country's rank among all countries covered by the aggregate indicator, with 0 corresponding to lowest rank, and 100 to highest rank. The hypothesis for voice and accountability for the study is as follows:

Hypothesis 6: Host country Voice and Accountability will have a positive association with inward FDI. 


\subsection{Methodology, Data and Estimation}

The primary objective of the paper is to analyse the trends and patterns of FDI inflows in South Asian countries, together with that we would like to find out the impact of institutional variables on the FDI inflows in these nations. Data for the current study is obtained for eight South Asian countries such as Afghanistan, Bangladesh, Bhutan, India, Maldives, Nepal, Pakistan and Sri-Lanka for the period of 1990-2015, from World Bank's various reports. The current study attempts to find out the impact of institutional variables on FDI inflows in South Asian countries, the time period of the study has been taken since 1990 . We would use a panel data for 8 countries for 26 years and the model is as under

$$
\begin{array}{r}
\log _{-} \mathrm{FDI}_{\mathrm{it}}=\alpha+\beta_{1} \mathrm{CR}_{\mathrm{it}}+\beta_{2} \mathrm{POLST}_{\mathrm{it}}+\beta_{3} \mathrm{GOVQ}_{\mathrm{it}}+\beta_{4} \mathrm{REG}_{\mathrm{it}}+\beta_{5} \mathrm{RULE}_{\mathrm{it}}+\beta_{6} \mathrm{ACC}_{\mathrm{it}}+ \\
\beta_{7} \mathrm{OPEN}_{\mathrm{it}}+\mu_{\mathrm{it}}
\end{array}
$$

where,

Log_FDI ${ }_{i t}$ is $\log$ of net Foreign Direct Investment in current US\$ millions for country $\mathrm{i}$ at time t.

$\mathrm{CR}_{\mathrm{it}}$ represents the Control of Corruption in the country $\mathrm{i}$ at time

POLST $_{\text {it }}$ represents the Political Stability and Absence of Violence/Terrorism in the country $\mathrm{i}$ at time $\mathrm{t}$.

$\mathrm{GOVQ}_{\mathrm{it}}$ is Quality of Government effectiveness and is believed to be an important institutional variable which effect level of FDI inflows into a country $i$ at time $t$.

$\mathrm{REG}_{\text {it }}$ represents the Regulatory Quality in the country i at time t

RULE $_{\mathrm{it}}$ is Rule of Law in the country $\mathrm{i}$ at time t.

$\mathrm{ACC}_{\mathrm{it}}$ is Voice and Accountability of the country $\mathrm{i}$ at time $\mathrm{t}$.

OPEN $_{\text {it }}$ is Trade Openness of the country i at time t,

The indicators, expected sign and the source of the explanatory variables are presented in the Table 1.

The expected impact of the independent variables on the level of FDI inflows is positive as the host country which is on the higher side in the control of corruption may attract more FDI inflows, the same sign is expected for the government effectiveness for instance, more the government is effective more is the development in the country and hence the foreign investment is expected to have positive relation with that country.

When we take political stability it is also expected that it may positively impact the level of FDI inflows in the host country as the business environment is friendly in the country. The expected signs of regulatory quality, rule of law and voice and accountability are again expected to be positive, if they all are at the satisfactory level in 
a country they may provide a better environment to the foreign investors into the host country.

Table 1: Expected Signs of the Explanatory Variables on FDI Inflows

\begin{tabular}{|l|c|l|}
\hline Variable & $\begin{array}{c}\text { Expected } \\
\text { Sign }\end{array}$ & Source \\
\hline Control of Corruption & + & World Governance Indicator, World Bank \\
\hline Government Effectiveness & + & World Governance Indicator, World Bank \\
\hline Political Stability & + & World Governance Indicator, World Bank \\
\hline Regulatory Quality & + & World Governance Indicator, World Bank \\
\hline Rule of Law & + & World Governance Indicator, World Bank \\
\hline Voice and Accountability & + & World Governance Indicator, World Bank \\
\hline Trade Openness & + & World Governance Indicator, World Bank \\
\hline Source: Compiled by author & &
\end{tabular}

\subsection{Empirical Results and Interpretation}

Table 2 presents the descriptive statistics of the variables. It shows the average, minimum and maximum estimates for the institutional variables.

Table 2: Descriptive Statistics of Variables

\begin{tabular}{|l|c|c|c|c|}
\hline \multicolumn{1}{|c|}{ Variables } & Minimum & Maximum & Mean & Std. Deviation \\
\hline Log of FDI & -5.43 & 1.24 & -.23 & .91 \\
\hline Trade openness & 7.96 & 11.67 & 9.60 & .84 \\
\hline Control of Corruption & -13.93 & 88.46 & 33.81 & 21.15 \\
\hline Government Effectiveness & -28.95 & 75.12 & 36.58 & 18.45 \\
\hline Political Stability & -45.36 & 95.65 & 20.96 & 25.88 \\
\hline Regulatory Quality & -5.16 & 73.53 & 31.56 & 16.17 \\
\hline Rule of Law & -2.12 & 73.10 & 36.13 & 18.44 \\
\hline Voice and Accountability & 4.48 & 61.50 & 30.29 & 13.13 \\
\hline
\end{tabular}

\subsection{Empirical results}

We consider the equation (1) for finding out the impact of institutional variables on the level of FDI inflows into the eight South Asian countries by using relevant method of Panel data analysis. A common panel data regression model looks like $Y_{i t}=a$ 
$+\mathrm{bx}_{\mathrm{it}}+\varepsilon_{\mathrm{it}}$ where, $\mathrm{y}$ is the dependent variable, $\mathrm{x}$ is the independent variable, $\mathrm{a}$ and $\mathrm{b}$ are coefficients, $i$ and $t$ are indices for individuals and time. The error is very important in this analysis. Assumptions about the error term determine whether we speak of fixed effects or random effects. In a fixed effects model, is assumed to vary non-stochastically over i or t making the fixed effects model analogous to a dummy variable model in one dimension. In a random effects model, is assumed to vary stochastically over i or $t$ requiring special treatment of the error variance matrix (Sury, 2008).

Using panel data analysis for a period of 1990-2015 on eight South Asian countries (except Afghanistan, data is available since 2002 only), Table 3 presents the result of Hausman test which is used to determine which method fits better Random Effect Model or Fixed Effect Model, first of all we run the model by using REM method, in Table 5.3 the $\mathrm{p}$ value is 0.0000 which is less the 0.05 so we can conclude that since $0.0000<0.05$ is significantly different from zero, we should not use random effects model.

\section{Table 3: Results of Hausman Test}

\begin{tabular}{|c|c|c|c|}
\hline \multicolumn{3}{|c|}{ Correlated Random Effects - Hausman Test } & \\
\hline \multicolumn{3}{|c|}{ Equation: Untitled } & \\
\hline \multicolumn{3}{|c|}{ Test cross-section random effects } & \\
\hline Test Summary & Chi-Sq. Statistic & Chi-Sq. d.f. & Prob. \\
\hline Cross-section random & 104.783657 & 7 & 0.0000 \\
\hline
\end{tabular}

As the appropriate model for our analysis is Fixed Effect Method the results are shown in the Table 4. We now concentrate on the possible impact of institutional variables as indicated by Eq. (1). We include control of corruption, government effectiveness, political stability, regulatory quality, rule of law, trade openness, voice and accountability to find out the impact of these variables on the level of FDI inflows in the above mentioned eight South Asian countries. Table 4 shows the estimation results of equation (1). The adjusted R-square indicates that 67.43 percent of the variation in the response variables can be explained by the institutional variables.

Using FEM the effect of institutional variables on South Asian countries has been established. The Table shows that out of seven variables, four variables turn out to be significant, the coefficient of control of corruption and regulatory quality are negative and significantly different from zero. This implies that control of corruption measures have negative impact on the location choice of the foreign investors it may be due to the reason that by paying bribes the administrative bottlenecks may be reduced, so it 
therefore supports the 'Helping Hand' theory of corruption and the results are similar to Wei (2000a; 2000b) and Campos et al (2010). The co-efficient of Regulatory quality is also negative the reason behind this may be the number of procedures and rules to be followed in the host country may be a hindrance for the foreign investors and which makes the country less attractive to the foreign investors.

Table 4: Estimation of Model

Dependent variable: Log value of FDI in South Asian Countries

\begin{tabular}{|l|l|l|l|l|}
\hline \multicolumn{1}{|c|}{ Variable } & Coefficient & \multicolumn{1}{c|}{ Std. Error } & t-Statistic & \multicolumn{1}{c|}{ Prob. } \\
\hline C & -6.725109 & 1.244887 & -5.402184 & 0.0000 \\
\hline Control of Corruption & -0.016076 & 0.004556 & -3.528869 & $0.0005 * * *$ \\
\hline Government Effectiveness & 0.054403 & 0.005600 & 9.714631 & $0.0000 * * *$ \\
\hline Political Stability & -0.004584 & 0.003435 & -1.334292 & 0.1838 \\
\hline Regulatory Quality & -0.012507 & 0.003776 & -3.311895 & $0.0011 * * *$ \\
\hline Rule of Law & -0.012519 & 0.008182 & -1.530030 & 0.1277 \\
\hline Trade openness & 0.609793 & 0.137273 & 4.442179 & $0.0000 * * *$ \\
\hline Voice and Accountability & 0.004490 & 0.006302 & 0.712539 & 0.4770 \\
\hline R-squared & 0.697631 & & \\
\hline Adjusted R-squared & 0.674372 & & \\
\hline Note *Significance at 10\% **Significance at 5\%,**Significance at 1\% &
\end{tabular}

Note: *Significance at $10 \%, * *$ Significance at $5 \%, * * *$ Significance at $1 \%$.

The coefficient of government effectiveness and trade openness are positive and significantly different from zero, the results of these two variables are as per our expectations because the Government effectiveness represents the development in a country and it is assumed that the foreign investors invest into a country with better infrastructure. The trade openness is again a very important institutional variable for these eight South Asian countries, it may be interpreted here that more a country is open more is likely to receive FDI inflows.

From the Table 4, it may be observed that the control of corruption turns out to be negative and significant and government effectiveness is positive and significant, the political stability is negative but insignificant on the other hand regulatory quality and rule of law are also negative and significant, trade openness is positive and significant and voice and accountability is also positive but insignificant. This implies that government effectiveness and trade openness matters a lot for the foreign investor to choose the location for investment, while control of corruption and regulatory quality have a negative effect on the level of inward FDI in South Asian countries, it may be because Multi National Enterprises invest in any location under strict contracts which 
have guaranteed protection by the central bank and international laws, the disputes are settled through international organisations so domestic rules and laws do not effect these organisations.

\subsection{Conclusion}

Do institutional variables affect FDI inflows into South Asian countries? The paper has offered answer to the above question by testing the hypotheses formulated using panel data analysis method. The study presents a better understanding of impact of institutional variables on FDI inflows in South Asian countries. The South Asian countries are adopting various kinds of reforms to liberalise their countries more and more, despite continues efforts the South Asian countries are not able to attract much FDI when compared to other regions of the world. However in the recent years the South Asian region has seen a pattern of growth in FDI inflows still it is concentrated only to the one or two countries of the region.

The objective of our study is to find out the impact of institutional determinants on FDI inflows in eight South Asian countries and the regression results presented above show that some of the hypotheses are accepted and some are rejected. In the study variables turn out to be significant are control of corruption, regulatory quality, government effectiveness and trade openness. The paper finds that the control of corruption has negative effect on FDI inflows in South Asian countries. The regulatory quality has a negative coefficient indicating that the number of procedures and rules to be followed in the host country becomes hindrance for the foreign investors. Further, the study concludes that countries with government effectiveness and trade openness attract relatively more FDI inflows in South Asian countries, while control of corruption and regulatory quality deterred the FDI inflows. The governments of these eight South Asian countries should undertake reforms to enhance the trade and should take steps to increase the effectiveness of the government to attract more FDI inflows.

\section{References}

Anghel, B. (2005). Do institutions affect foreign direct investment? International doctorate in economic analysis, Universidad Autónoma de Barcelona, 2-40.

Asiedu, E. (2006). Foreign direct investment in Africa: The role of natural resources, market size, government policy, institutions and political instability. The World Economy, 29(1), 63-77. 
Barassi, M. R., \& Zhou, Y. (2012). The effect of corruption on FDI: a parametric and non-parametric analysis. European Journal of Political Economy, 28(3), 302-312.

Barnes, I., \& Davison, L. (1994). European business. Butterworth Heinenmann, Oxford.

Belderbos, R., \& Carree, M. (2002). The location of Japanese investments in China: Agglomeration effects, keiretsu, and firm heterogeneity. Journal of the Japanese and International Economies, 16(2), 194-211.

Blanc-Brude, F., Cookson, G., Piesse, J., \& Strange, R. (2014). The FDI location decision: Distance and the effects of spatial dependence. International Business Review, 23(4), 797-810.

Busse, M. (2004). Transnational corporations and repression of political rights and civil liberties: An empirical analysis. Kyklos, 57(1), 45-65.

Campos, N.F., Estrin, S., \& Proto, E. (2010). Corruption as a barrier to entry: theory and evidence. IZA Research Paper, vol. 5243. Institute for the Study of Labour (IZA), Bonn.

Chen, C. (2011). Foreign direct investment in China, location determinants, investor difference and economic impacts. Cheltenham UK: Edward Elgar Publishing.

Cheng, L. K., \& Kwan, Y. K. (2000). What are the determinants of the location of foreign direct investment? The Chinese experience. Journal of International Economics, 51(2), 379-400.

Curwen, P., \& Hartley, K. (1997). Privatisation: Understanding the UK economy. 4th edition, Basingstoke: Macmillan.

Deichmann, U., Lall, S. V., Redding, S. J., \& Venables, A. J. (2008). Industrial location in developing countries. The World Bank Research Observer, 23(2), 219-246.

Du, J., Lu, Y., \& Tao, Z. (2012). Institutions and FDI location choice: The role of cultural distances. Journal of Asian Economics, 23(3), 210-223. 
42 | FOCUS: Journal of International Business, Volume 4, Issue 2, July-December 2017

Dunning, J. H. (2001). The key literature on IB activities: 1960-2000. In A.M. Rugman and T.L. Brewer (eds), The Oxford Handbook of International Business, pp. 36-68. Oxford: Oxford University Press.

Dunning, J. H. (2002). Regions, globalization, and the knowledge-based economy. Oxford: Oxford University Press.

Gatignon, H., \& Kimberly, J. R. (2004). Globalization and its challenges. In H. Gatignon, J.R. Kimberly and R.E. Gunther. (eds.) The INSEAD-Wharton Alliance on Globalizing: Strategies for Building Successful Global Business, pp. 1-22. Cambridge University Press: Cambridge.

Godinez, J. R., \& Liu, L. (2015). Corruption distance and FDI flows into Latin America. International Business Review, 24(1), 33-42.

Grosse, R., \& Trevino, L. J. (2005). New institutional economics and FDI location in Central and Eastern Europe. MIR: Management International Review, 45(2), 123-145.

International Monetary Fund (IMF), (2004). Definition of Foreign Direct Investment (FDI) terms, IMF Committee on Balance of Payments Statistics and OECD workshop on International Investment Statistics. Retrieved from http://www.imf.org/External/ $\mathrm{NP} / \mathrm{Sta} / \mathrm{bop} / \mathrm{pdf} / \mathrm{diteg} 20 . \mathrm{pdf}$

Jadhav, P. (2012). Determinants of foreign direct investment in BRICS economies: Analysis of economic, institutional and political factor. Procedia-Social and Behavioral Sciences, 37, 5-14.

Jain, A. K. (2001). Corruption: A review. Journal of Economic Surveys, 15(1), 71-121.

La Porta, R., Lopez-de-Silanes, F., Shleifer, A., \& Vishny, R. (1999). The quality of government. The Journal of Law, Economics, and Organization, 15(1), 222-279.

Li, S., \& Park, S. H. (2006). Determinants of locations of foreign direct investment in China. Management and Organization Review, 2(1), 95-119.

Mengistu, A. A., \& Adhikary, B. K. (2011). Does good governance matter for FDI inflows? Evidence from Asian economies. Asia Pacific business review, 17(3), 281-299. 
Narayan, L. (2014). Determinants of foreign direct investment in Indian. International Journal of Research, 1(7), 815-823.

Okafor, G. (2015). Locational determinants of US outward FDI into sub-Saharan Africa. The Journal of Developing Areas, 49(1), 187-205.

Pournarakis, M., \& Varsakelis, N. (2004). Institutions, internationalization and FDI: the case of economies in transition. Transnational Corporations, 13(2), 77-94.

Smarzynska, B. K., \& Wei, S. J. (2000). Corruption and composition of foreign direct investment: Firm-level evidence (Vol. 7969). Cambridge, MA: National Bureau of Economic Research.

Sury, N. (2008). Determinants of foreign direct investment in Indian. Foreign Trade Review, 42(4), 24-41.

Wei, S.-J. (2000a). How taxing is corruption on international investors. The Review of Economics and Statistics, 82(1), 1-11.

Wei, S.-J. (2000b). Local corruption and global capital flows. Brooking Papers on Economic Activity, 31(2), 303-354.

World Bank (1997). Helping countries combat corruption: The role of the World Bank. Poverty Reduction and Economic Management Network. September.

Yu, J., \& Walsh, J. P. (2010). Determinants of foreign direct investment: A sectoral and institutional approach. IMF Working Paper WP/10/187, Asian Pacific Department. 